\title{
Post-Irradiation Ageing Effect on Cytological Characters of Crotalaria Saltiana
}

\author{
A.B.S. Shah, A. Akhter, A. Naz ${ }^{1}$, M.M. Ud-Deen ${ }^{2 *}$ and G. Kabir ${ }^{3}$ \\ Professor Sultanul Alam Cytogenetics Laboratory, Department of Botany, \\ University of Rajshahi, Rajshahi-6205, Bangladesh \\ ${ }^{1}$ Department of Botany, Fulbari Govt. College, Fulbari, Dinajpur \\ ${ }^{2}$ Department of Crop Science \& Technology, University of Rajshahi, Rajshahi-6205 \\ ${ }^{3}$ Department of Botany, University of Rajshahi, Rajshahi-6205 \\ *Corresponding author: uddeenm@yahoo.com
}

\begin{abstract}
Post-irradiation ageing effect on different cytological characters of Crotalaria saltiana were studied. Mitotic index followed no decreasing or increasing tendency based on the doses of gamma rays. Interphase chromosome volume was not found to increase with an increase of gamma rays. Percentage of pollen sterility was found to be lower in the lower doses and higher in the higher doses. Irregularities such as, formation of fragments, bridges, laggards, single and multiple chromatid bridges, unequal distribution and abnormal nuclear arrangement were recorded. This study reflects that irradiated seeds of Crotalaria saltiana showed no such dose wise effect and that might be due to ageing effect for long time.
\end{abstract}

\section{Introduction}

The species Crotalaria saltiana belongs to the family Fabaceae and it has been growing naturally under the prevailing environmental condition of Bangladesh.

Ageing is the universal physiological phenomenon occurring in living organisms. Usually it starts with a faster rate under stresses of unfavorable condition and normally proceeds at a slower pace as programmed by the genetic information specific to the species under adapted condition [1]. It is a well known fact that the stored seeds may become a problem in modern agricultural practices [2, 3].

It has been shown that ageing of seeds not only increase the frequency of spontaneous chromosomal aberrations, but also increase the sensitivity of the chromosomes to the effect of X-rays [4, 5]. Nilan and Gunthardt [6] found that the frequency of spontaneous chromosomal aberrations in root tip cells of wheat increased with the age of seeds from $0.02 \%$ to $0.43 \%$ in 1 to 17 years old seed, 
respectively. However, it gradually become apparent that chronological age of the seed is not the factor involved in the production of chromosome aberrations only. It is evidenced that factors such as temperature and moisture during storage are also important. The importance of temperature during storage has also been highlighted by many investigators [6, 7]. It is shown that heat treatments induce chromosome breakage. Treatment of barley seeds at $95^{\circ} \mathrm{C}$ for 25 minutes or at $40^{\circ} \mathrm{C}$ at high humidity for 30 days resulted chromosomal aberrations [7]. In addition to temperature and humidity, oxygen can contribute to the induction of chromosomal aberration. The production of chromosome damage during the ageing of seeds probably depends on the integration with time of the collective effects of these three factors. Production of chromosomal mutation by ionizing radiation is a common phenomenon in the field of cytogenetics. Reports on this aspect are very adequate now a days and the effect of irradiation on Crotalaria saltiana has been reported several times. But information regarding effect of natural ageing on irradiated plant materials is not available. Particularly this type of work on Crotalaria saltiana is scanty. The present investigation was aimed to evaluate the cytological changes in plants raised from thirty two years old irradiated (naturally) aged seeds of Crotalaria saltiana.

\section{Materials and Methods}

Thirty two years old irradiated (naturally) seeds of Crotalaria saltiana were used as plant material. Dry seeds of Crotalaria saltiana were irradiated with gamma rays by $5000 \mathrm{ci} \mathrm{Co}^{60}$ source at the rate of $10,20,30,40,50,60,70,80,90$ and $100 \mathrm{Kr}$ from the Atomic Energy Center, Dhaka. Seeds were obtained from Professor S.Alam Cytogenetics Laboratory, Department of Botany, Rajshahi University, Rajshahi for the present study.

Part of the seeds was germinated on moist filter paper in petri dishes at room temperature in the laboratory and another part was germinated in pots. Germination percentages were recorded after seven days in laboratory and twelve day in pot. Root tips were collected and fixed into 1:3 acetic acid-alcohol for 48 hours and stored in $70 \%$ ethanol. Temporary slides were prepared by squash method using haematoxylin [8]. Data were recorded on mitotic index, interphase chromosome volume (ICV) and various mitotic abnormalities from different stages. The mitotic index was obtained as follows:

No. of dividing cells

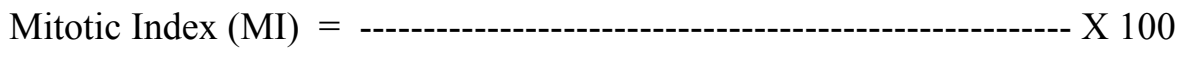

No. of studied cells (dividing + non-dividing)

The nuclear volume (NV) was calculated using the formula for a sphere, NV = $4 / 3 \pi r^{3}$ [9]. The mean nuclear volume divided by the somatic chromosome number resulted the ICV. 
For meiotic study, young inflorescence obtained from dry seeds of Crotalaria saltiana which were irradiated with gamma rays by $5000 \mathrm{ci} \mathrm{Co}^{60}$ source at the rate of $10,20,30,40,50,60,70,80,90$ and $100 \mathrm{Kr}$ were collected in 1:3 acetoalcohol. After 24-36 hours of fixation they were transferred to $70 \%$ ethanol. To collect data on meiotic abnormalities and pollen sterility, temporary slides were prepared from suitable anthers by acetocarmine smear technique. Pollen grain sterility was calculated as follows:

Total no. of sterile pollen grain

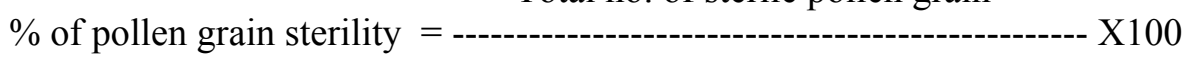

Total no. of fertile + sterile pollen grain

The findings obtained from the experiment were analyzed statistically MSTAT-C package program. The mean values recorded for all the treatments were compared by Duncun's Multiple Range Test (DMRT) [10].

\section{Results and Discussion}

The frequency of the mitotic index (MI), interphase chromosome volume (ICV) and mitotic abnormalities are summarized in Table 1 and Plate A 1-6. Maximum values for mitotic index $(6.97 \%)$ was found due to $20 \mathrm{Kr}$ and that was statistically identical with that of 10,40 and $60 \mathrm{Kr}$. On the other hand, the lowest value $(1.81 \%)$ of it was recorded due to $80 \mathrm{Kr}$ and that value was statistically identical with that of all other treatments except 20 and $40 \mathrm{Kr}$. In the present study post irradiation ageing resulted in lower percentage of dividing cell. It was reported that depression of cell division was observed obviously in the root of 10 years old wheat and barley seeds where the mitotic index reached not more than 3.07 and $3.15 \%$ compared to $8.71 \%$ and $10.21 \%$ in root tips of one year old seeds $[11,12]$. A considerable fall in the mitotic index of Lens and Pisum induced by chlorinated hydrocarbon was found [13]. The present findings might be due to the presence of any toxic materials present in the aged seeds of Crotalaria saltiana produced due to exhaustion of respiratory reserve substances and caused mitotic inhibition.

Maximum interphase chromosome volume $\left(0.889 \mu^{3}\right)$ was observed in case of 70 $\mathrm{Kr}$ and the minimum $\left(0.037 \mu^{3}\right)$ was observed in case of $40 \mathrm{Kr}$ (Table 1$)$. The combined effect of post irradiation and ageing in ICV indicated that with an increase of gamma rays there was no increase in ICV among the doses. Although it was found that the ICV increased with an increase of age in wheat and barley seeds $[14,15]$. On the other hand it was found that ICV increased with an increase of gamma rays in wheat [16] and in Crotalaria juncea [17]. It was found that irradiated seeds of Crotalaria saltiana showed no such dose wise effect and that might be due to ageing effect for long time.

Mitotic root tip cells of post-irradiation aged Crotalaria saltiana showed various types of chromosomal irregularities (Plate A 1-6). Most of the abnormalities were 
Table 1. Post-irradiation ageing effects on mitotic index (MI), interphase chromosome volume (ICV) and mitotic abnormalities in the root tip cells of Crotalaria saltiana

\begin{tabular}{|c|c|c|c|c|c|c|c|}
\hline \multirow{2}{*}{ Treatments } & \multirow{2}{*}{$\begin{array}{c}\text { MI } \\
(\%)\end{array}$} & \multirow{2}{*}{$\begin{array}{c}\text { ICV } \\
\left(\mu^{3}\right)\end{array}$} & $\begin{array}{c}\text { No. of } \\
\text { cells } \\
\text { studied }\end{array}$ & $\begin{array}{c}\text { Mean } \\
\text { abnormality } \\
(\%)\end{array}$ & \multicolumn{2}{|c|}{ \% of different abnormalities } \\
\cline { 8 - 10 } & & & Bridges & Laggards & $\begin{array}{c}\text { Frag- } \\
\text { ments }\end{array}$ \\
\hline $20 \mathrm{Kr}$ & $4.50 \mathrm{abc}$ & $0.728 \mathrm{~b}$ & 132.56 & $0.94 \mathrm{~cd}$ & 0.50 & 0.16 & 0.16 \\
\hline $30 \mathrm{Kr}$ & $6.97 \mathrm{a}$ & $0.481 \mathrm{~d}$ & 92.22 & $0.71 \mathrm{~cd}$ & 0.48 & 0.12 & 0.12 \\
\hline $40 \mathrm{Kr}$ & $4.94 \mathrm{ab}$ & $0.264 \mathrm{f}$ & 151.77 & $0.87 \mathrm{~cd}$ & 0.58 & 0.07 & 0.21 \\
\hline $50 \mathrm{Kr}$ & $4.05 \mathrm{bc}$ & $0.435 \mathrm{de}$ & 169.00 & $1.48 \mathrm{bcd}$ & 0.78 & 0.26 & 0.32 \\
\hline $60 \mathrm{Kr}$ & $4.36 \mathrm{abc}$ & $0.401 \mathrm{e}$ & 117.89 & $1.84 \mathrm{~b}$ & 1.31 & 0.18 & 0.28 \\
\hline $70 \mathrm{Kr}$ & $2.97 \mathrm{bc}$ & $0.889 \mathrm{a}$ & 129.44 & $1.33 \mathrm{bcd}$ & 0.94 & 0.08 & 0.08 \\
\hline $80 \mathrm{Kr}$ & $1.81 \mathrm{c}$ & $0.456 \mathrm{de}$ & 162.77 & $1.10 \mathrm{bcd}$ & 0.95 & 0.06 & 0.06 \\
\hline $90 \mathrm{Kr}$ & $3.35 \mathrm{bc}$ & $0.401 \mathrm{e}$ & 153.11 & $1.53 \mathrm{bc}$ & 0.94 & 0.14 & 0.21 \\
\hline $100 \mathrm{Kr}$ & $3.07 \mathrm{bc}$ & $0.654 \mathrm{c}$ & 108.22 & $3.04 \mathrm{a}$ & 1.64 & 0.41 & 0.71 \\
\hline
\end{tabular}

Means followed by the same letter(s) do not differ statistically at 5\% level tested by DMRT

Table 2. Post-irradiation ageing effects on meiotic abnormalities and pollen sterility of Crotalaria saltiana

\begin{tabular}{|l|c|c|c|c|c|c|c|}
\hline \multirow{2}{*}{$\begin{array}{c}\text { Treatm } \\
\text { ents }\end{array}$} & $\begin{array}{c}\text { No. of } \\
\text { cells } \\
\text { studied }\end{array}$ & $\begin{array}{c}\text { Mean } \\
\text { abnor- } \\
\text { mality } \\
(\%)\end{array}$ & Bridges & $\begin{array}{c}\text { Frag- } \\
\text { ments }\end{array}$ & Laggards & $\begin{array}{c}\text { Nuclear } \\
\text { arrange- } \\
\text { ment } \\
\text { (Telophase } \\
\text { II) of } \\
\text { nucleus }\end{array}$ & $\begin{array}{c}\text { Pollen } \\
\text { sterility } \\
(\%)\end{array}$ \\
\hline $10 \mathrm{Kr}$ & 84.11 & $3.763 \mathrm{abc}$ & 1.66 & 0.92 & 0.66 & $1.52 \mathrm{bc}$ & $2.67 \mathrm{e}$ \\
\hline $20 \mathrm{Kr}$ & 108.66 & $2.78 \mathrm{c}$ & 0.90 & 1.12 & 0.61 & $1.36 \mathrm{bc}$ & $1.33 \mathrm{f}$ \\
\hline $30 \mathrm{Kr}$ & 79.11 & $3.328 \mathrm{bc}$ & 1.56 & 0.98 & 0.70 & $1.83 \mathrm{~b}$ & $5.33 \mathrm{~d}$ \\
\hline $40 \mathrm{Kr}$ & 83.77 & $4.704 \mathrm{ab}$ & 1.79 & 1.85 & 0.92 & $2.04 \mathrm{ab}$ & $2.66 \mathrm{e}$ \\
\hline $50 \mathrm{Kr}$ & 90.11 & $4.327 \mathrm{abc}$ & 1.83 & 1.84 & 0.73 & $1.94 \mathrm{~b}$ & $12.67 \mathrm{~b}$ \\
\hline $60 \mathrm{Kr}$ & 91.00 & $5.08 \mathrm{a}$ & 1.97 & 2.07 & 1.34 & $3.54 \mathrm{a}$ & $21.33 \mathrm{a}$ \\
\hline $70 \mathrm{Kr}$ & 88.33 & $4.786 \mathrm{a}$ & 0.88 & 2.51 & 0.88 & $2.57 \mathrm{ab}$ & $7.33 \mathrm{c}$ \\
\hline $80 \mathrm{Kr}$ & 86.33 & $4.928 \mathrm{a}$ & 1.15 & 2.31 & 1.41 & $3.56 \mathrm{a}$ & $6.00 \mathrm{~cd}$ \\
\hline
\end{tabular}

Means followed by the same letter(s) do not differ statistically at 5\% level tested by DMRT 
characterized by chromosome fragments, lagging chromosomes, bridges etc. In case of certain doses some cells showed diverse types of chromosomal abnormalities such as bridges and fragments, bridges and lagging chromosomes, fragments and lagging chromosomes in a single cell. The highest percentage of mitotic abnormality (3.04\%) was observed due to $100 \mathrm{Kr}$ which was significantly different from that of all other treatments. Whereas the lowest percentage $(0.65 \%)$ was found due to $40 \mathrm{Kr}$ and that was statistically similar with that of all other treatments except 60, 90 and $100 \mathrm{Kr}$ (Table 1).

The percentage of abnormality was not found to be increased with an increase of the doses of gamma rays. Although it was observed that in Crotalaria juncea the percentage of abnormalities was increased with an increase of the gamma rays [17]. Similar result was also noticed by other authors in Lathyrus sativus [18] and in Vicia ervil [19] treated with gamma rays. However, in the present study it was observed that the percentage of abnormalities was not vary high in comparison to the above mentioned reports by different workers, although ageing was an additional agent in this study. Thus, it indicated that ageing caused chromosomal aberrations but not like the gamma rays. The present findings indicated that the post irradiation ageing was not effective to increase the frequency of chromosomal aberrations. However, it was found that the frequencies of aberrant cells were higher when the storage time increased [20]. The very much effective rate of mitotic irregularities in root tip cells might be accelerated by temperature and radiation than ageing.

Meiotic study in the pollen mother cells (PMCs) of Crotalaria saltiana plants raised from the seeds treated with different doses of gamma rays and ageing showed various types of chromosomal abnormalities such as fragments, bridges, lagging chromosomes, multivalent and irregular distribution (Plate B 1-6 and Table 2). The highest percentage of meiotic abnormalities $(5.08 \%)$ was observed in case of $60 \mathrm{Kr}$ which was statistically similar with that of all other treatments except 20 and $30 \mathrm{Kr}$. Whereas the lowest $(2.78 \%)$ was found in $20 \mathrm{Kr}$ and that was statistically similar with that of 10,30 and $50 \mathrm{Kr}$. Post-irradiation ageing affected the chromosomes during meiosis of Crotalaria saltiana and the percentage of abnormalities was high due to higher doses but haphazardly. It was not found to be increased sometimes in higher doses but not with the increase of gamma rays [17]. Effect was similarly to that type as it was found in somatic cell. It was reported that above $10 \%$ chromosomal irregularities in higher doses in Clotaria juncea and Clotaria sericea due to treatment with gamma ray [21]. Although other authors observed that the percentage of abnormalities was increased with an increase of the gamma rays in Crotalaria juncea and Clotaria sericea $[17,22]$. Similar result was also noticed in tetraploid and hexaploid wheat [23]. However, in the present study meiotic abnormalities were observed in decreased rate when the irradiated seed were kept in moisture free desicator for a 
long time. Such decrease of the abnormal cell proved that the ageing may be important factor for reducing the mutagenic effect of gamma ray. Several workers have reported that the percentage of meiotic abnormalities was increased with an increase of the age. It was observed that post-irradiation ageing increased the meiotic abnormalities [16] but in the present study result was reverse. The percentage of abnormalities was not found to be increased with increase of the dose of gamma ray and it was a noticeable matter in this study. It might be due to ageing effect for long time.
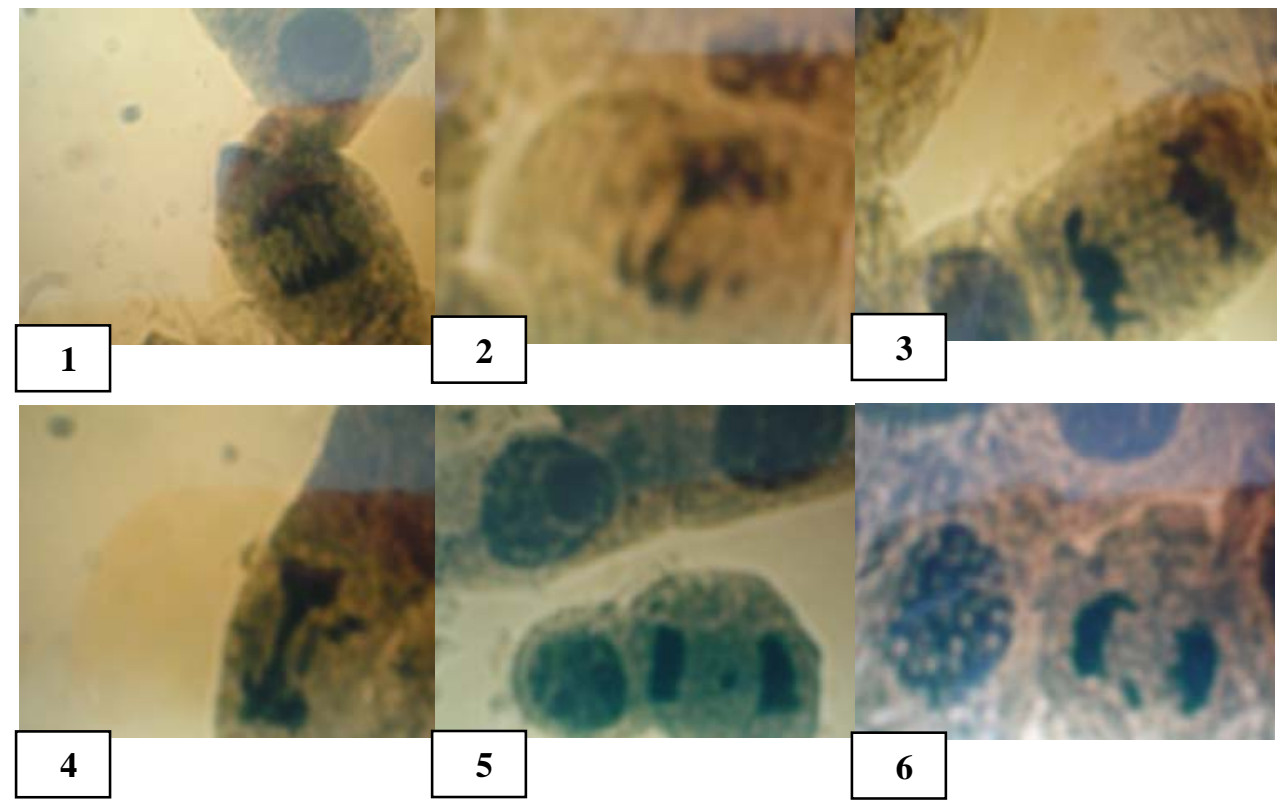

Plate A 1-6: Micrographs showing different types of mitotic abnormalities in the root tip cells of Crotalaria saltiana induced by gamma rays and ageing. 1. Anaphase with multiple bridge, 2. Early telophase with fragment and bridge, 3. Telophase with two bridge, 4 . Telophase with multiple bridge and fragments, 5. Telophase with fragments and $\mathbf{6}$. Telophase with laggard.

At the end of meiosis II (tetrad condition) nuclear arrangement in some cases were bipolar and tripolar. In normal cases the nuclear arrangement was found to be tetrapolar. Highest percentage of abnormal arrangement of nucleus was found to be $3.56 \%$ at $80 \mathrm{Kr}$ and the lowest one $(1.36 \%)$ was found in case of $20 \mathrm{Kr}$ (Table 2). There was tendency of increase or decrease of this abnormality along with the increase or decrease of the doses of gamma rays. In this investigation abnormal nuclear arrangement was observed with low frequency in all the doses. 
The normal arrangement of nucleus at the end of meiosis II is considered to be tetrapolar. But in the present study with predominance of tetrapolar arrangement few cells at telophase II stage were found with bipolar and tripolar arrangement. These abnormalities might be due to ageing effect. However, no such report has been found regarding this type of abnormality.
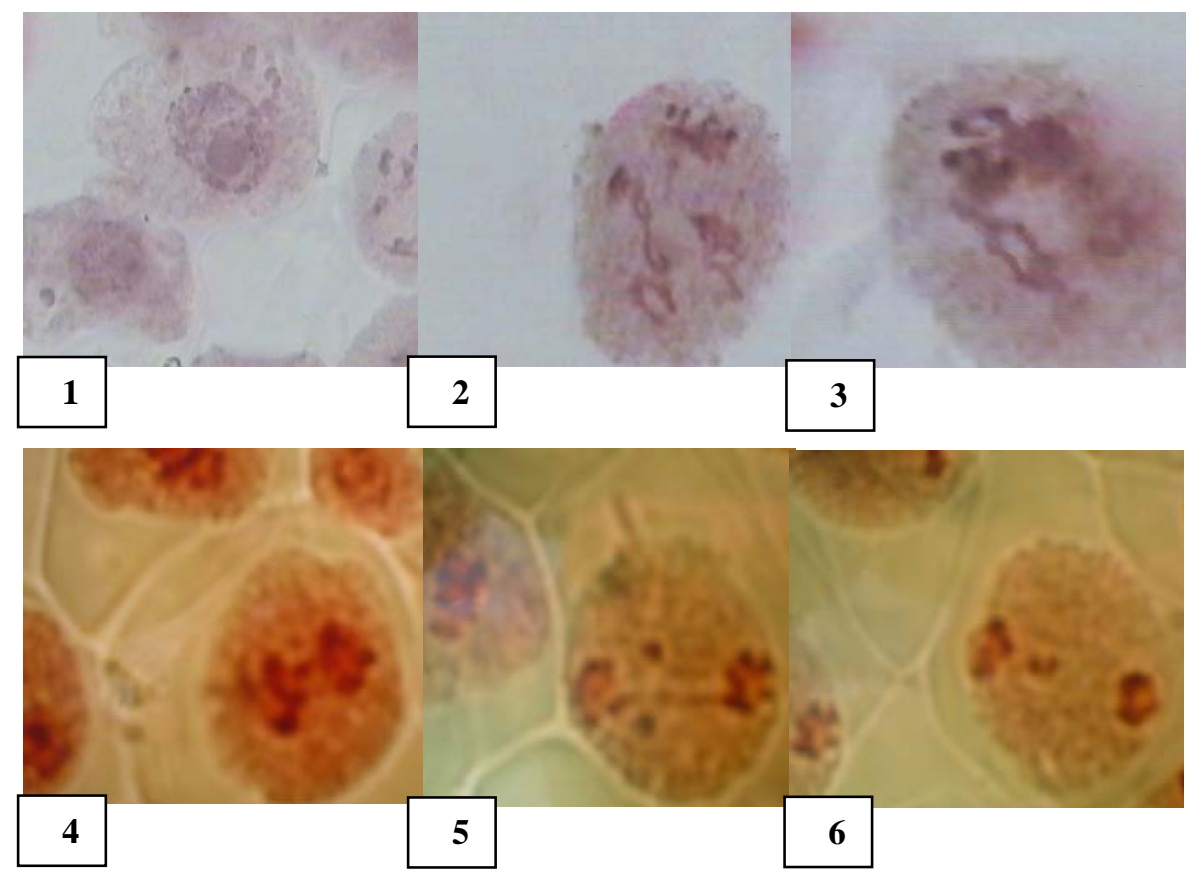

Plate B 1-6: Micrographs showing different types of meiotic abnormalities in the pollen of Crotalaria saltiana due to gamma rays and ageing. 1. PMC with 8 bivalents, 2. PMC with a trivalent (univalent not detected), 3. PMC with a quadrivalent, 4. Anaphase II with multiple bridges, 5. Telophase I with single bridge and two fragments and $\mathbf{6}$. Telophase I with laggard.

The maximum percentage of pollen sterility $(21.33 \%)$ was observed due to $60 \mathrm{Kr}$ and that value was different significantly from that of all other treatments (Table $2)$. On the other hand, the lowest percent of pollen sterility $(1.33 \%)$ was found due to $20 \mathrm{Kr}$ and here also the value significantly differed with that of other treatments. The percentages of pollen sterility were found to be lower in the lower doses and higher in the higher doses. Although, it was reported that increased of pollen sterility with an increase of the doses of gamma rays plus ageing in both tetra and hexaploid wheat [23]. However, naturally in any 
flowering plants more or less $5 \%$ pollens are found to be sterile. So, compared to this phenomenon frequency of sterile pollens against all the doses except 50 and $60 \mathrm{Kr}$ were statistically non-significant. In many previous reports the combined effect of irradiation and ageing in case of pollen sterility showed the deteriorative effect. But the present finding was somewhat different and that might be due to compensating effect of ageing.

\section{Conclusion}

In the present findings post-irradiation ageing responded to different cytological characters of Crotalaria saltiana. The combined effect of post-irradiation and ageing indicated that with an increase of gamma rays there were no increase in mitotic index, ICV and percent of abnormality but showed various types of chromosomal irregularities.

\section{References}

1. Strehler, B.L.: Cells and ageing. Acadimic Press, N.Y pp. 4-32. (1962).

2. Crocker, W. and Barton, L.V.: Chronica Botanica, Waltham, Mass. pp. 140-151. (1983).

3. Nutile, G.E.: Crop Sci. 4, 325-328. (1974).

4. Blakeslee, A.F. and Avery, A.G.: Abstract. Amer. Nat. 68, 466. (2000).

5. Caldecott, R.S.: International Atomic Energy Agency-Vienna. p. 3-24. (2003).

6. Nilan, R.A. and Gunthardt, H.M.: Cytol. 8, 316-322. (1986).

7. Peto, F.H.: Can. For. Res. 9, 261-264. (1973).

8. Haque, A., Ali, M.A., Wazuddin, M. and Khan, M.A.: Curr. Sci. 45(10), 382-383. (1976).

9. Nayer, G.G., George, K.P. and Gopal, A.R.: Radiation Bot. 2, 175-178. (1970).

10. Gomez, K.A. and Gomez, A.A.: John Wiley and Sons. Inc. New York p. 214. (1984).

11. Akhter, F.N., Kabir, G., Mannan M.A, and Saheen, N.N.: J. Islamic Academy Sci. 5, 44-48. (1992).

12. Abdalla, F.H. and Roberts, E.H.: Ann. Bot. 32, 119-136. (2001). 
13. Jain, K.A. and Sarbhoy, R.K.: Cytol. 52, 47-53. (1987).

14. Akhter, F.N.: Ageing effects in wheat and barley, and the mutagenic efficiency of their seed extracts. M. Sc. Thesis. Dept. of Botany, University of Rajshahi. (1990).

15. Cartledge, J.L. and Blakeslee, A.F.: Proc. Nat. Acad. Sci. 20, 103-110. (1999).

16. Paul, D.: Post-irradiation ageing effect on chromosomal structural changes and yield in wheat. M. Phil. Thesis. Dept. of Botany, University of Rajshahi. (1994).

17. Islam, S.M.S.: Cytomorphological changes in mutation spectrum of Crotalaria juncea L. in relation to three physical factors. M. Sc. Thesis. Dept. of Botany, University of Rajshahi. (1993).

18. Shaikh, M.A.Q.: Bangladesh Sci. Conf. Rajshahi. p. 72. (1972).

19. Emery, D.A., Boardman, E.G. and Stucker, R.E.: Radiation Bot. 10, 267-272. (2001).

20. Murata, M., Roos, E.E. and Tsuchiya, T.: Canadian J. Gent. Cytol. 23, 267-280. (1981).

21. Khan, M.R.: Cytological and cytogenetical studies in Crotalaria. M. Sc. Thesis. Dept. of Botany, University of Rajshahi. (1981).

22. Khan, M.R. and Alam, S.: J. Bot. 13(2), 185-193. (1984).

23. Paul, D. and Kabir, G.: Rajshahi University Studies, Part B. Journal of Sci. 34, 195-204. (2006). 